\title{
Pengembangan Bahan Ajar Interaktif Melalui Aplikasi Ispring untuk Mengeksplor Kemampuan Representasi Matematis
}

\author{
Irna Nuraeni ${ }^{1}$, Nani Ratnaningsih ${ }^{2}$, Sri Tirto Madawistama ${ }^{3}$ \\ 1, 2 Program Studi Pendidikan Matematika Pascasarjana Universitas Siliwangi, \\ Jl. Siliwangi No.24, Kahuripan, Tawang, Tasikmalaya, Jawa Barat 46115 \\ irnanuraeni98@yahoo.com
}

\begin{abstract}
The purpose of developing teaching materials through the ispring application is to determine the quality of the effectiveness of the use of teaching materials through the ispring application on statistical materials. Teaching materials in it include material, sample questions, videos, and quizzes. The GeoGebra application was chosen because it is easy to use and has complete features. This research and development used the ADDIE method, namely: (1) Analysis, (2) Design, (3) Development, (4) Implementation, (5) Evaluation. Data collection techniques in this study used observation, needs analysis questionnaires, namely learning media and subject matter, student ability questionnaires, interviews, validation sheets given to 2 media experts and 2 material experts, limited trial user response questionnaires given to 8 participants. class XII students of SMK Al - Huda Sariwangi and 2 mathematics teachers, a questionnaire was given to 31 students of class XII of SMK Al Huda Sariwangi, then a pretest and posttest of mathematical representation skills. Based on the research results, interactive teaching materials through the ispring application are valid and can be used from media experts and material experts. The results of the limited trial and implementation obtained the "good" category. The results of the effect size (ES) test obtained a value of 1.83 with the "strong effect" category. It can be concluded that the interactive teaching materials developed are valid and can be used by students in learning
\end{abstract}

Keywords: Teaching Materials, Ispring Applications, Statistics

\begin{abstract}
Abstrak
Tujuan dari pengembangan bahan ajar melalui aplikasi ispring ini adalah untuk mengetahui kualitas efektivitas penggunaan bahan ajar melalui aplikasi ispring pada materi statistika. Bahan ajar di dalamnya terdapat materi, contoh soal, video dan quiz. Aplikasi Ispring dipilih karena mudah digunakan dan mempunyai fitur yang lengkap. Penelitian dan pengembangan ini menggunakan metode ADDIE yaitu: (1) Analisis, (2) Design, (3) Development, (4) Implementation, (5) Evaluasi. Teknik pengumpulan data dalam penelitian ini menggunakan observasi, angket analisis kebutuhan yaitu media pembelajaran dan materi pelajaran, angket kemampuan peserta didik, wawancara, lembar validasi yang diberikan kepada 2 ahli media dan 2 ahli materi, angket respon pengguna uji coba terbatas yang diberikan kepada 8 peserta didik kelas XII SMK Al - Huda Sariwangi dan 2 guru matematika, angket diberikan kepada 31 peserta didik kelas XII SMK Al - Huda Sariwangi, kemudian pretest dan posttest kemampuan representasi matematis. Berdasarkan hasil penelitian, bahan ajar interaktif melalui aplikasi ispring ini valid dan dapat digunakan dari ahli media dan ahli materi. Hasil uji coba terbatas dan implementasi diperoleh kategori "baik". Hasil pengujian effect size (ES) diperoleh nilai 1,83 dengan kategori "strong effect". Dapat disimpulkan bahwa bahan ajar interaktif yang dikembangkan valid dan dapat digunakan oleh peserta didik dalam pemebalajaran.
\end{abstract}

Kata kunci: Bahan Ajar, Aplikasi Ispring, Statistika

Copyright (c) 2022 Irna Nuraeni, Nani Ratnaningsih, Sri Tirto Madawistama

$\triangle$ Corresponding author: Irna Nuraeni

Email Address: irnanuraeni98@yahoo.com (Jl. Siliwangi No.24, Kahuripan, Tawang, Tasikmalaya, Jawa Barat) Received 09 December 2021, Accepted 12 January 2022, Published 28 February 2022

\section{PENDAHULUAN}

Matematika merupakan pelajaran paling dasar yang digunakan untuk mempelajrai ilmu lainnya. Sejalan dengan Buyung \& Nirawati (2018) yang menyatakan bahwa matematika merupakan salah satu mata pelajaran yang memegang peranan yang sangat penting dalam pendidikan karena matematika dapat mengembangkan setiap kemampuan serta keterampilan kepada peserta didik untuk digunakan dalam mempelajari ilmu lain. Mengingat pentingnya proses pembelajaran matematika maka pendidik dituntut untuk mampu menyelesaikan, memilih, dan memadukan sumber pembelajaran 
Pengembangan Bahan Ajar Interaktif Melalui Aplikasi Ispring untuk Mengeksplor Kemampuan Representasi Matematis, Irna Nuraeni, Nani Ratnaningsih, Sri Tirto Madawistama 1009

yang tepat dalam setiap pembelajaran matematika. Pengembangan bahan ajar penting dilakukan oleh pendidik agar pembelajaran lebih efektif, efisien, dan tidak melenceng dari kompetensi yang akan dicapainya. Dalam suatu pembelajaran, bahan ajar merupakan salah satu hal yang sangat penting. Bahan ajar merupakan alat pembelajaran yang digunakan oleh pendidik untuk menciptakan suasana pembelajaran yang berisi materi dan dikemas secara sistematis yang menuntut peserta didik untuk belajar menurut Ifdhal (dalam Al Adiyah et al , 2018). Dengan menggunakan bahan ajar kepada peserta didik, pendidik tidak perlu terlalu banyak dalam menyampaikan materi. Bahan ajar merupakan bagian dari sumber belajar. Untuk membantu peserta didik dalam mencapai tujuan pembelajaran, bahan ajar memegang peranan penting. Depdiknas (dalam Purmadi dan Surjono, 2016), menjelaskan bahwa bagian penting dalam pelaksanaan pendidikan di sekolah salah satunya adalah bahan ajar. Maksudnya pendidik akan lebih mudah dalam melaksanakan pembelajaran dengan menggunaan bahan ajar.

Bahan ajar yang dikembangkan dengan berbagai variasi akan membuat kegiatan pembelajaran menjadi lebih menarik. Keberhasilan kegiatan pembelajaran dapat diperoleh apabila terdapat komponen yang dikembangkan oleh pendidik, yaitu tujuan, materi, strategi, dan evaluasi pembelajaran. Dengan mengembangkan bahan ajar yang dapat menimbulkan gairah peserta didik dalam belajar merupakan salah satu upaya pendidik melakukan upaya mencapai keberhasilan dalam pembelajaran (Hosnan, 2016), tetapi dari hasil wawancara peneliti dengan salah satu pendidik matematika di SMK Al Huda Sariwangi, yang menyatakan bahwa beberapa pendidik belum menggunakan media yang beragam, masih berupa buku (media cetak) atau file pdf yang di share di whatsapp bahkan belum ada pendidik yang mengembangkan bahan ajar dengan menggunakan aplikasi yang membuat kegiatan pembelajaran menjadi lebih interaktif, yang terjadi karena beberapa pendidik masih kurang dalam membiasakan pemanfaatan media pembelajaran yang lebih interaktif dan ini yang menjadi alasan peneliti pemilihan SMK Al - Huda Sariwangi menjadi tempat penelitian. Dengan berbagai permasalahan diatas maka dengan mengembangkan bahan ajar interaktif yang lebih mudah dipelajari menjadikan peserta didik lebih termotivasi dalam belajar matematika.

Perkembangan teknologi saat ini menuntut semua elemen dalam pendidikan harus lebih menguasai teknologi. Bahkan di masa pandemi, maraknya layanan belajar jarak jauh atau pembelajaran daring maka menuntut para pendidik matematika untuk dapat menguasai ilmu matematika sekaligus metode pembelajaran yang terkini berbasis teknologi. Sesuai salah satu prinsip pembelajaran Kurikulum 2013 pada Permendikbud No. 65 Tahun 2013 yaitu pemanfaatan teknologi informasi dan komunikasi untuk meningkatkan efisiensi dan efektivitas pembelajaran. Menurut Permendikbud tersebut dapat disimpulkan bahwa begitu besar peran teknologi dalam pembelajaran matematika, salah satunya sebagai alat bantu agar seluruh peserta didik dapat mengakses pembelajaran matematika di manapun mereka berada. Pembelajaran berbasis teknologi dikenal dengan e-learning. Salah satu aplikasi yang bisa dimanfaatkan pendidik sebagai media pembelajaran adalah Ispring, menurut Cahyati (2018) Ispring merupakan salah satu tool yang mengubah file 
presentasi menjadi bentuk Flash dan bentuk SCORM / AICC, yaitu bentuk yang biasa digunakan dalam pembelajaran dengan e-learning LMS (Learning Management System). Perangkat lunak Ispring tersedia dalam versi free (gratis) dan berbayar. Aplikasi Ispring juga tidak hanya menyajikan fitur-fitur tentang materi ajar, namun juga bisa digunakan sebagai media evaluasi dari penugasan yang diberikan oleh pendidik. Ispring dapat dimanfaatkan sebagai sarana pembuatan e-learning, mempermudah dalam penyampaian materi. Aplikasi E-learning sendiri adalah sebuah proses pembelajaran yang berbasis elektronik.

Dalam pengembangan bahan ajar ini, peneliti berfokus pada materi statistika karena statistika merupakan salah satu materi pelajaran yang cukup sulit untuk dipahami bagi peserta didik dalam mata pelajaran matematika. Hal ini sejalan dengan Pujiastuti (dalam Fajriah, Utami dan Mariyam, 2020) materi statistika menunjukkan sebagian besar peserta didik masih lemah dalam menyampaikan ide melalui lisan atau teks tertulis. Selain itu, menurut Selviani (2017) dalam penelitiannya Statistika merupakan salah satu pokok bahasan pada pelajaran matematika yang kurang disukai dan dianggap sulit oleh peserta diidk, karena dalam materi ini peserta didik bosan untuk menghitung data yang disajikan, dan sering dari mereka melakukan kesalahan dalam perhitungan. Dapat disimpulkan bahwa, peserta didik masih kesulitan dalam mempelajari materi Statistika.

Pembelajaran yang tepat dapat mendorong timbulnya rasa senang peserta didik terhadap pelajaran, menumbuhkan dan lebih termotivasi dalam mengerjakan tugas, memberikan kemudahan bagi peserta didik untuk memahami pelajaran sehingga memungkinkan peserta didik mencapai hasil belajar yang lebih baik. Dalam mengatasi permasalahan ini, para pendidik memerlukan pengajaran yang inovatif. Sebagai langkah perbaikan pembelajaran matematika, pendidik hendaknya dapat membantu peserta didik, sehingga hasil belajar peserta didik lebih baik lagi. Pendidik matematika harus mampu menerjemahkan matematika yang dianggap rumit oleh peserta didik, menjadi bentuk yang mudah dipahami oleh peserta didik (Permata, Sukestiyarno, dan Hindarto, 2017).

Dalam proses penelitian pengembangan terdapat beragam metode penelitian, pada penelitian ini peneliti mengambil model ADDIE yang terdiri dari lima komponen yaitu (A)nalysis, (D)esign, (D)evelopment, (I)mplementation, dan (E)valuation. Menurut Aldoobie dalam (Setiyani et al., 2019) model ADDIE adalah salah satu model yang banyak digunakan di bidang desain pembelajaran untuk menghasilkan desain yang efektif. Adapun untuk mengetahui keefektifan pengembangan bahan ajar interaktif melalui Aplikasi Ispring pada materi Statistika untuk mengeksplor kemampuan representasi matematis peserta didik peneliti menggunkan Effect Size menurut Cohen, Mannion dan Marisson (2007) dalam menghitungnya.

Penelitian sebelumnya Himmah \& Martini (2017) mengungkapkan bahwa penggunaan Ispring dengan penyajian yang menarik dapat memotivasi belajar peserta didik lebih baik. Beberapa penelitian tentang pengembangan bahan ajar interaktif telah dilakukan, tetapi belum ada yang mengembangkan bahan ajar melalui Aplikasi Ispring pada materi Statistika. 
Pengembangan Bahan Ajar Interaktif Melalui Aplikasi Ispring untuk Mengeksplor Kemampuan Representasi Matematis, Irna Nuraeni, Nani Ratnaningsih, Sri Tirto Madawistama

1011

\section{METODE}

Jenis penelitian yang digunakan dalam penelitian ini adalah metode penelitian dan pengembangan (Reseach and Develovment). Tujuan metode penelitian pengembangan ini digunakan untuk menghasilkan produk tertentu dalam menguji keefektifan produk tersebut, maka diperlukan penelitian untuk menguji keefektifan produk tersebut (Sugiyono, 2017). Pada penelitian ini dikembangkan bahan ajar dengan Aplikasi Ispring yang memuat materi Statistika. Tujuan dari penelitian ini adalah menghasilkan produk berupa bahan ajar interaktif menggunakan Aplikasi Ispring pada materi Statistika. Penelitian pengembangan pada penelitian ini menggunakan model ADDIE (Analysis, Design, Development, Implementation, dan Evaluation) yang dikembangkan oleh (Branch, 2009), berikut tahapan pengembangan bahan ajar melaui aplikasi ispring dengan model addie dapat dilihat pada gambar di bawah ini.

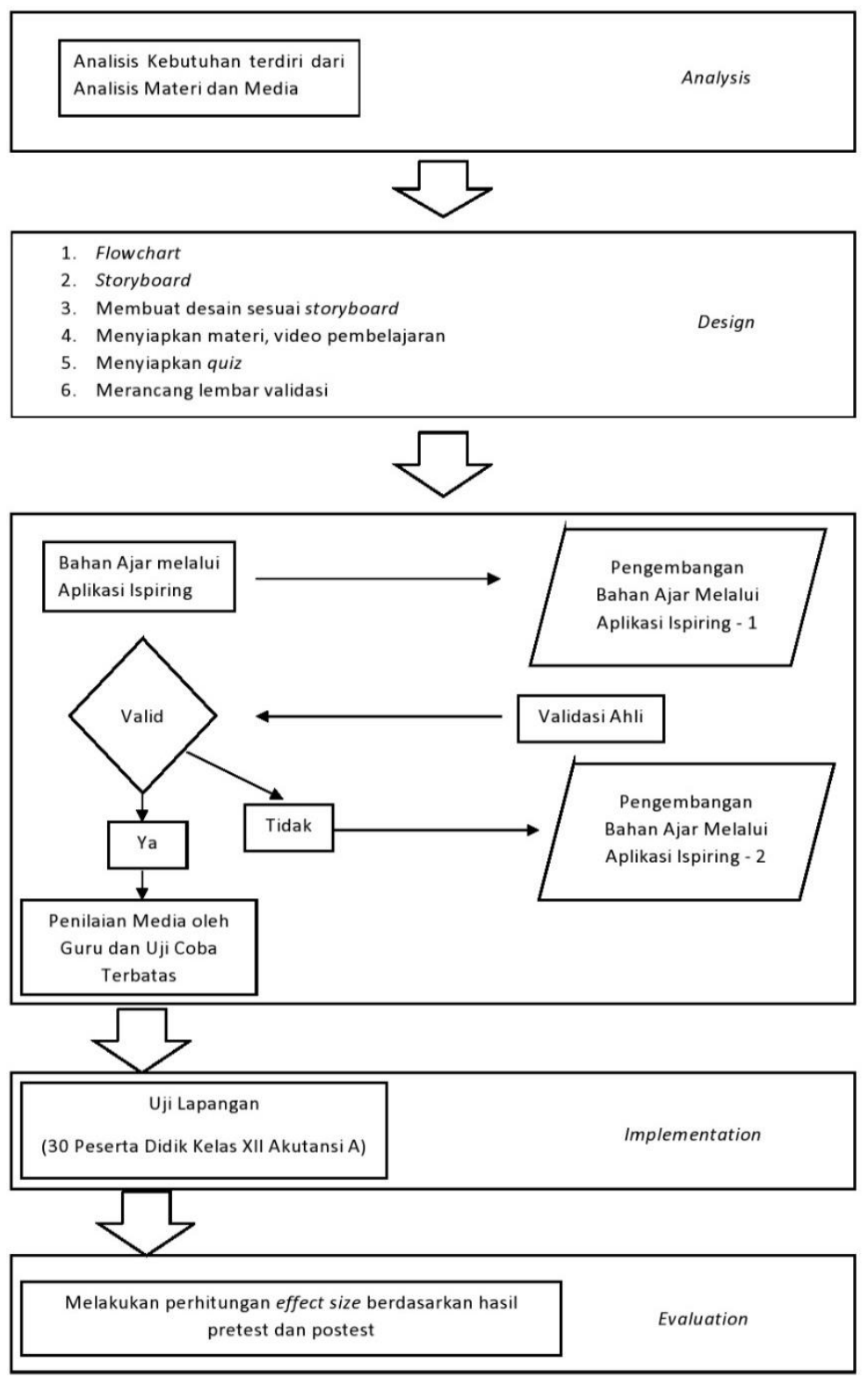

Gambar 1. Tahapan Pengembangan Bahan Ajar Melalui Aplikasi Ispring Dengan Model Addie 
Berikut penjelasan tahapan - tahapannya:

\section{Analysis (Analisis)}

Tahap analisis yang dilakukan oleh peneliti yaitu mengidentifikasi suatu permasalahan dan kebutuhan yang diperoleh dari sekolah. Melalui wawancara di SMK Al - Huda Sariwangi terhadap pendidik matematika maka diperoleh data terkait analisis kebutuhan yaitu meliputi data mengenai media pembelajaran berupa bahan ajar interaktif dan materi pelajaran. Hal ini sesuai dengan hasil penelitian Zain \& Pratiwi (2021) yang menyatakan bahwa kebutuhan guru yang ditemukan di lapangan, berdasarkan hasil observasi yang dilakukan sebagian besar guru membutuhkan media pembelajaran yang dapat membantu proses pembelajaran. Pada analisis media yang berupa bahan ajar dilakukan dalam rangka menganalisis media yang akan dikembangkan dalam memodifikasi bahan ajar melalui Aplikasi Ispring untuk pembelajaran matematika. Pemilihan media yang dikembangkan yaitu dengan mempertimbangkan kemudahan dalam membuat dan penggunaan yang menjadikan peserta didik lebih termiotivasi dalam belajar matematika dengan Aplikasi Ispring sebagaimana yang telah mengembangkan oleh penelitian terlebih dahulu. Selanjutnya, analisis materi pelajaran dilakukan dalam rangka menganalisis materi yang akan digunakan dalam memodifikasi bahan ajar melalui Aplikasi Ispring untuk pembelajaran matematika. Pemilihan materi yang digunakan yaitu dengan melalui proses wawancara dengan pendidik matematika di SMK Al - Huda Sariwangi.

\section{Design (Desain)}

Rancangan bahan ajar yang akan dikembangkan terlebih dahulu menyiapkan materi berkaitan dengan statistika yaitu ukuran pemusatan data tunggal dan kelompok setelah itu menyiapkan video pembelajaran, menyiapkan latihan soal, dan evaluasi pembelajaran berupa quiz pada Ispring. Selanjutnya, Merancang dan memvalidasi lembar penilaian dan angket respon peserta didik yang akan digunakan sebagai alat pengumpul data validasi media, validasi materi, dan respon peserta didik untuk mengetahui kelayakan bahan ajar yang dikembangkan. Hal ini sesuai dengan penelitian yang dilakukan oleh Rosmiati \& Siregar (2021) yang menyatakan bahwa pada tahap desain, peneliti mulai menyusun tujuan yang ingin dicapai, membuat storyboard media pembelajaran, dan membuat konten atau materi mata pelajaran. Setelah seluruh komponen dalam mendesain Bahan Ajar melalui Aplikasi Ispring selesai dibuat maka selanjutnya dilanjutkan dengan tahap development.

\section{Development (Pengembangan)}

Tahapan ini merupakan tahap pengembangan dari tahap desain. Pada tahap ini dilakukan pengembangan produk awal bahan ajar, yaitu sebagai berikut: Mempublish bahan ajar oleh Ispring, HTML 5 dan Website 2, menghasilkan produk bahan ajar melalui Aplikasi Ispring yang dapat diakses melalui link yang dibagikan, menyiapkan perangkat pembelajaran dalam rangka mengetahui efektivitas pada materi Statistika melalui Aplikasi Ispring, yaitu seperti menyiapkan bahan evaluasi dengan format essay untuk mengetahui kualitas efektivias pada materi Statistika, setelah itu 
Pengembangan Bahan Ajar Interaktif Melalui Aplikasi Ispring untuk Mengeksplor Kemampuan Representasi Matematis, Irna Nuraeni, Nani Ratnaningsih, Sri Tirto Madawistama

1013

melakukan uji ahli pada produk dari bahan ajar yang telah dikembangkan akan diuji kelayakannya oleh ahli (validator) media dan materi agar produk yang dihasilkan memenuhi standar dan kebutuhan peserta didik. Uji validitas ini akan menggunakan instrumen berupa angket yang nantinya angket tersebut akan diwawancarakan sehingga akan terlihat apakah bahan ajar Aplikasi Ispring perlu direvisi atau tidak. Hal ini sejalan dengan hasil penelitian Zakiy, Syazali, \& Farida (2018) yang menyatakan bahwa apabila materi sudah dinyatakan valid maka materi tersebut layak digunakan sebagai bahan ajar yang dikembangkan. Selanjutnya, Melakukan uji coba terbatas setelah bahan ajar interaktif melalui Aplikasi Ispring dinyatakan valid dan layak digunakan maka langkah selanjutnya adalah diujikan secara terbatas kepada beberapa orang peserta didik kelas XII di SMK Al - Huda Sariwangi dan pendidik yang mengajar matematika. Untuk mengetahui keterbacaan dari bahan ajar yang peneliti kembangkan maka akan diberikan angket respon yang nantinya angket respon tersebut akan diwawancarakan. Untuk perhitungan angket respon peneliti menggunakan Tabel sebagai berikut.

Tabel 1. Kategori Skor Angket Respon Peserta Didik

\begin{tabular}{|c|l|}
\hline Skor & \multicolumn{1}{|c|}{ Kategori } \\
\hline 4 & Sangat Dipahami \\
\hline 3 & Dapat Dipahami \\
\hline 2 & Kurang Dipahami \\
\hline 1 & Tidak Dipahami \\
\hline
\end{tabular}

(Sundayana, 2014)

Untuk menentukan interpretasi dilakukan dengan langkah sebagai berikut.

(a) Menentukan skor maksimum ( $\left.\mathrm{S}_{\text {maks }}\right)$

$\mathrm{S}_{\mathrm{maks}}=$ banyak butir angket $\mathrm{x}$ banyak responden $\mathrm{x} 4$

(b) Menentukan skor minimum $\left(\mathrm{S}_{\mathrm{min}}\right)$

$\mathrm{S}_{\min }=$ banyak butir angket $\mathrm{x}$ banyak responden $\mathrm{x} 1$

(c) Menentukan rentang

Rentang $=$ skor maksimum - skor minimum

(d) Menentukan panjang kelas (p)

$\mathrm{p}=\frac{\text { Rentang }}{\text { banyak kategori }}$

(e) Menentukan skala tanggapan

Berikut interpretasi skala tanggapan

Tabel 2. Interpretasi Skala Tanggapan

\begin{tabular}{|l|l|}
\hline Skor Total $(\mathrm{ST})$ & Interpretasi \\
\hline $\mathrm{S}_{\min } \leq \mathrm{ST}<\mathrm{S}_{\min }+\mathrm{p}$ & Sangat Jelek \\
\hline $\mathrm{S}_{\min }+\mathrm{p} \leq \mathrm{ST}<\mathrm{S}_{\min }+2 \mathrm{p}$ & Jelek \\
\hline $\mathrm{S}_{\min }+2 \mathrm{p} \leq \mathrm{ST}<\mathrm{S}_{\min }+3 \mathrm{p}$ & Cukup \\
\hline $\mathrm{S}_{\min }+3 \mathrm{p} \leq \mathrm{ST}<\mathrm{S}_{\min }+4 \mathrm{p}$ & Baik \\
\hline $\mathrm{S}_{\min }+4 \mathrm{p} \leq \mathrm{ST}<\mathrm{S}_{\operatorname{maks}}$ & Sangat Baik \\
\hline
\end{tabular}


Apabila bahan ajar yang telah dikembangkan tersebut telah dinyatakan layak untuk digunakan dalam pembelajaran maka tahap selanjutnya adalah melakukan implementasi.

\section{Implementation (Implementasi)}

Langkah ini merupakan pengaplikasian bahan ajar melalui Aplikasi Ispring pada materi Statistika. Tahap implementasi akan menghasilkan data yang dapat digunakan untuk menganalisis aspek kepraktisan, kebermanfaatan, dan kualitas bahan ajar serta untuk mengetahui kualitas efektivitas kemampuan representasi matematis pada materi Statistika melalui produk dari bahan ajar yang peneliti kembangkan. Setelah bahan ajar Aplikasi Ispring dinyatakan valid dan layak digunakan maka langkah selanjutnya adalah melakukan uji lapangan terhadap satu kelas yaitu kelas XII. Untuk mengetahui respon peserta didik terhadap produk dari bahan ajar yang dikembangkan maka akan diberikan angket yang nantinya angket tersebut akan diwawancarakan. Hal ini sesuai dengan penelitian yang telah dilakukan oleh Hayati, Budi, \& Handoko (2015) yaitu bahwa pada tahapan implementasi, media yang sudah dinyatakan layak digunakan selanjutnya dilakukan uji lapangan. Selain itu, untuk mengetahui kualitas efektivitas bahan ajar Aplikasi Ispring maka akan diberikan soal tes uraian pada materi Statistika dengan Rumus ES yang digunakan dengan berdasarkan rumus Cohen, Mannion dan Marisson (2007), yaitu:

$$
E S=\frac{\text { mean of posttest-mean of pretest }}{\text { standar deviation of pretest }}
$$

Berikut ini pada Tabel 3.14 merupakan klasifikasi interpretasi hasil perhitungan Effect Size (ES).

Tabel 3. Klasifikasi Effect Size

\begin{tabular}{|c|c|}
\hline Besarnya Effect Size & Interpretasi \\
\hline $0-0.20$ & Weak effect \\
\hline $0.21-0.50$ & Modest effect \\
\hline $0.51-1.00$ & Moderat effect \\
\hline$>1.00$ & Strong effect \\
\hline (Cohen, Manion, \& Marrison, 2007) \\
\hline
\end{tabular}

\section{Evaluation (Evaluasi)}

Tujuan dari langkah evaluasi ini adalah bahan ajar melalui Aplikasi Ispring untuk pada materi Statistika dapat dijadikan sebagai referensi bagi pendidik dan peserta didik dalam pembelajaran. Evaluasi ini yaitu akan mengukur keefektifan dari pengembangan bahan ajar melalui Aplikasi Ispring dengan diberikannya soal. Evaluasi bahan ajar melalui Aplikasi Ispring pada penelitian ini juga berdasarkan hasil penilaian ahli media, ahli materi, dan respon peserta didik yang selanjutnya diwawancarakan untuk mengetahui lebih jelas mengenai kelayakan, kepraktisan, dan kebergunaan penggunaan bahan ajar yang dikembangkan. 
Pengembangan Bahan Ajar Interaktif Melalui Aplikasi Ispring untuk Mengeksplor Kemampuan Representasi Matematis, Irna Nuraeni, Nani Ratnaningsih, Sri Tirto Madawistama 1015

\section{HASIL DAN DISKUSI}

\section{Analisis (Analysis)}

Pada tahap analisis (analysis) ini sesuai dari apa yang sudah dikemukakan pada bab pendahuluan yaitu menganalisis materi dan media yang digunakan di sekolah. Analisis materi masih kurangnya penyampaian materi yang mendalam dan menarik untuk siswa, sehingga siswa kurang termotivasi untuk belajar matematika. Pada analisis media yang diperoleh bahwa masih kurangnya penggunaan media pembelajaran yang terdapat di sekolah.

\section{Design}

Pada tahap desain (design) Aplikasi Ispring yang akan di buat bermula pada pembuatan flowchart, storyboard, menyiapkan materi yang akan ada pada bahan ajar tersebut, latihan soal untuk quiz dan soal pretest posttest. Dengan tampilan pada bahan ajar melalui aplikasi ispring yaitu menu petunjuk, kompetensi, materi termasuk didalamnya video penjelasan, quiz untuk latihan soal dan profil pengembang.
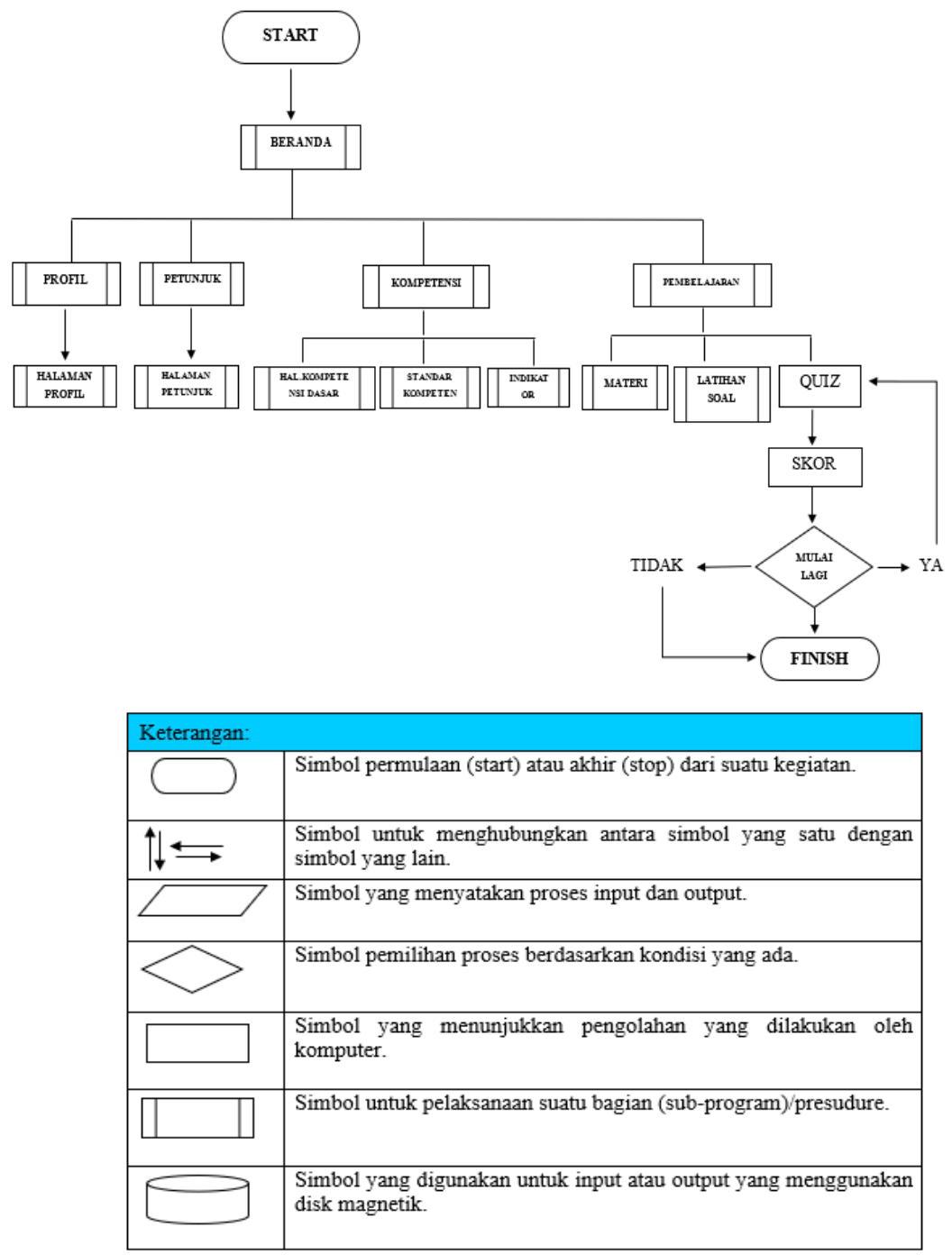

Gambar 2. Flowchart Bahan Ajar melalui Aplikasi Ispring 
Berikut storyboard yang dirancang.

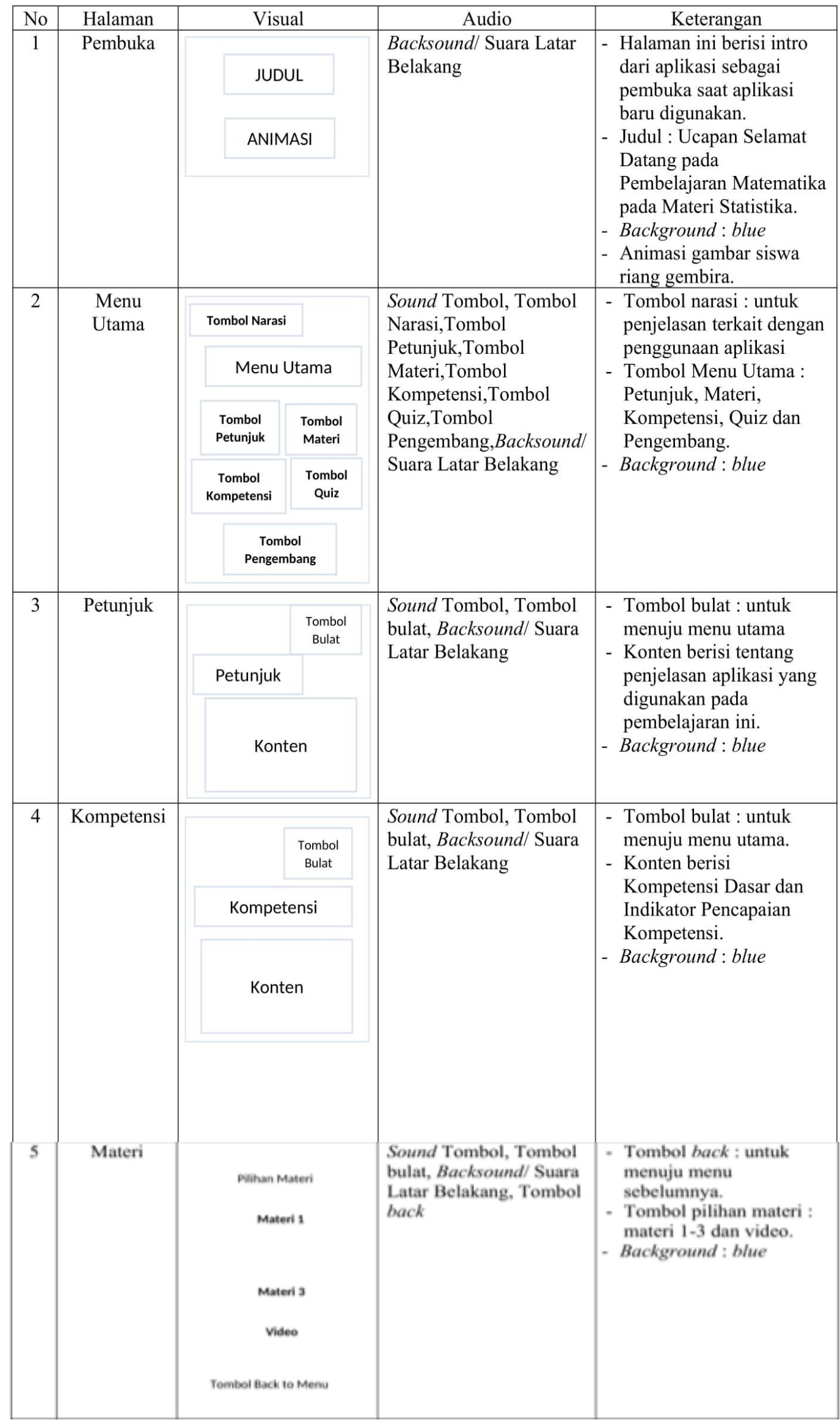


Pengembangan Bahan Ajar Interaktif Melalui Aplikasi Ispring untuk Mengeksplor Kemampuan Representasi Matematis, Irna Nuraeni, Nani Ratnaningsih, Sri Tirto Madawistama 1017

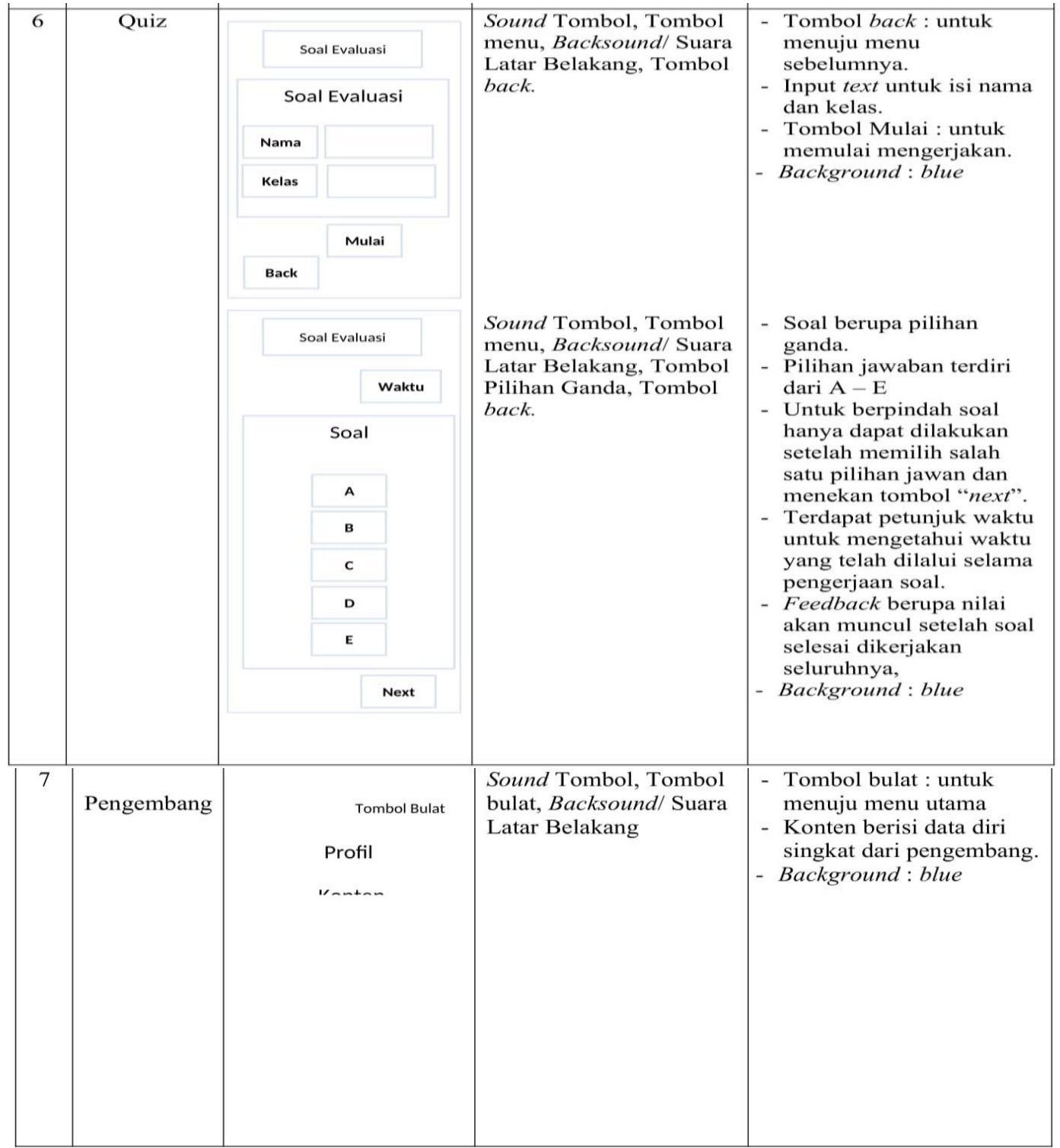

Gambar 3. Storyboard bahan ajar melalui aplikasi Ispring

\section{Development}

Selanjutnya masuk pada tahap pengembangan (development) bahan ajar yang sudah disiapkan, pada tahap ini dilakukan uji validasi soal, materi dan media. Berikut merupakan pembahasan yang dilakukan oleh para uji validasi dimulai dari ahli soal yaitu oleh ahli 2 dosen Magister Pendidikan matematika, materi yang telah dimasukan ke dalam bahan ajar yang dikembangkam sudah valid tetapi dengan revisi, setelah revisi bahan ajar dikatakan valid untuk digunakan berikut hasil revisi dari ahli soal.

Tabel 4. Komentar dan Saran Validator Ahli Soal

\begin{tabular}{|c|c|}
\hline Komentar & Saran \\
\hline $\begin{array}{c}\text { Soal yang dibuat } \\
\text { point }\end{array}$ & Memberikan point terhadap soal \\
\hline $\begin{array}{c}\text { Tidak ada alternative } \\
\text { jawaban }\end{array}$ & $\begin{array}{c}\text { Diberikan alternative jawaban dalam } \\
\text { penyelesaian soal }\end{array}$ \\
\hline
\end{tabular}


Memberikan point terhadap soal dan diberikan alternative jawaban dalam penyelesaian soal. Pada tabel 4 dijelaskan komentar serta saran yang telah diberikan oleh validator soal berikut merupakan contoh soal yang belum dan sudah direvisi.

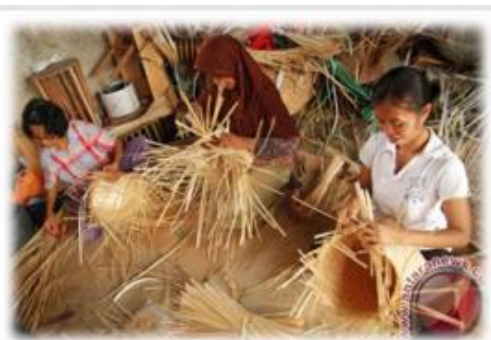

Ciamis merupakan sebuah kabupaten yang terletak di sebelah selatan Provinsi Jawa Barat. Ciamis terkenal dengan daerahnya yang masih asri dan memiliki banyak perkebunan juga lahan pertanian seperti masih banyaknya hutan-hutan bambu. Hasil dari hutan bambu ini dimanfaatkan oleh warga sekitar untuk membuat kerajinan anyaman bambu yang akhimya dijual. Salah satu daerah yang terkenal dengan kerajinan anyaman bambunya ialah Kecamatan Rajadesa. Banyak warga di sana yang bekerja sebagai buruh industri kerajinan anyaman bambu dengan upah yang beragam. Diketahui data mengenai upah buruh industri anyaman bambu tersebut tersaji pada tabel distribusi frekuensi di bawah ini dalam puluhan ribu rupiah

\begin{tabular}{|c|c|}
\hline Upah & Frekuensi \\
\hline $40-59$ & 6 \\
\hline $60-79$ & 8 \\
\hline $80-99$ & 22 \\
\hline $100-119$ & 8 \\
\hline $120-139$ & 6 \\
\hline
\end{tabular}

Suatu hari petugas kecamatan di sana ingin mendata rata-rata pendapatan upah buruh kerajinan anyaman bambu tersebut. Bagaimana cara ia mendapatkan hasil yang diinginkan? Berapa rata-rata upah buruh tersebut? UMR Kabupaten Ciamis pada saat ini Rp 1.880.654,54, kategori penduduk dikatakan berpenghasilan rendah jika upah yang ia dapatkan lebih kecil dari UMR dan dikatakan dikatakan berpenghasilan rendah jika upah yang ia dapatkan lebih kecil dari UMR dan dikatakan "Rata-rata pekerja kerajinan anyaman bambu berpenghasilan tinggi"!

Gambar 4. Soal sebelum revisi

\section{Kerjakan soal di bawah ini!}

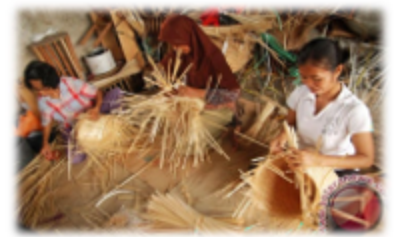

Ciamis merupakan sebuah Kabupaten yang terletak di sebelah selatan Provinsi Jawa Barat. Ciamis terkenal dengan daerahnya yang masih asri dan memiliki banyak perkebunan juga lahan pertanian seperti masih banyalny hutan-hutan bambu. Hasil dari hutan bambu ini dimanfaatkan oleh warga sekitar untuk membuat kerajinan anyaman bambu yang akhimya dijual. Salah satu daerah yang terkenal dengan kerajinan anyaman bambunya ialah Kecamatan Rajadesa. Banyak warga di sana yang bekerja sebagai buruh industri kerajinan anyaman bambu dengan upah yang beragam. Diketahui data mengenai upah buruh industri anyaman bambu tersebut tersaji pada tabel distribusi frekuensi di bawah ini dalam puluhan ribu rupiah.

\begin{tabular}{|c|c|}
\hline Upah & Frekuensi \\
\hline $40-59$ & 6 \\
\hline $60-79$ & 8 \\
\hline $80-99$ & 22 \\
\hline $100-119$ & 8 \\
\hline $120-139$ & 6 \\
\hline
\end{tabular}

Suatu hari petugas Kecamatan di Rajadesa ingin mendata rata-rata pendapatan upah buruh kerajinan anyaman bambu tersebut. Jika UMR Kabupaten Ciamis pada saat ini Rp $1.880 .654,54$ kategori penduduk dikatakan berpenghasilan rendah jika upah yang ia dapatkan lebih kecil dari UMR dan dikatakan berpenghasilan tinggi jika mendapat penghasilan di atas UMR

a. Berapaksah hasil rata-rata upah buruh tersebut?

b. Buktikan kebenaran pernyataan "Rata-rata pekerja kerajinan anyaman bambu berpenghasilan tinggi"!

Gambar 5. Soal setelah revisi 
Pengembangan Bahan Ajar Interaktif Melalui Aplikasi Ispring untuk Mengeksplor Kemampuan Representasi Matematis, Irna Nuraeni, Nani Ratnaningsih, Sri Tirto Madawistama 1019

Selanjutnya, dilakukan validasi terhadap media yaitu validator ahli meteri yaitu ahli materi pembelajaran matematika dari Dosen Magister Pendidikan Matematika dan guru SMK Al - Huda Sariwangi. Materi yang akan dimasukan ke bahan ajar yang telah dikembangkan sudah valid dengan beberapa revisi agar materi menjadi lebih menarik dan dapat dimengerti, berikut merupakan saran dan komentar yang diberikan oleh ahli materi.

Tabel 5. Komentar dan Saran Validator Ahli Materi

\begin{tabular}{|c|c|}
\hline Komentar & Saran \\
\hline $\begin{array}{c}\text { Pada materi pada contoh soal dalam } \\
\text { alternative jawaban pada satu slide. }\end{array}$ & $\begin{array}{c}\text { Alternatif jawaban pada contoh soal } \\
\text { dibuat pada slide yang berbeda }\end{array}$ \\
\hline Terdapat penulisan kata yang masih typo & $\begin{array}{c}\text { Kembali dilihat dan diperbaiki kata - } \\
\text { kata yang typo }\end{array}$ \\
\hline
\end{tabular}

Dan selanjurnya, dilakukan validasi terhadap media yaitu validator ahli media yaitu ahli media pembelajaran Dosen IT dan guru produktif SMK. Media pada penelitian ini adalah berupa bahan ajar melalui aplikasi ispring yang telah dikembangkan sudah valid dengan beberapa revisi agar media menjadi lebih baik, berikut merupakan saran dan komentar yang diberikan oleh ahli media.

Tabel 6. Komentar dan Saran Validator Ahli Media

\begin{tabular}{|l|l|}
\hline Komentar & Saran \\
\hline Audio disesuikan dengan materi & $\begin{array}{l}\text { Sebaiknya mengunakan audio yang berupa } \\
\text { instrument }\end{array}$ \\
\hline $\begin{array}{l}\text { Tidak ada tombol menu dari tiap } \\
\text { slide }\end{array}$ & $\begin{array}{l}\text { Menambahkan tombol menu pada setiap } \\
\text { slide }\end{array}$ \\
\hline
\end{tabular}

Pada tabel 6 yang berisi komentar dan saran dari validator ahli media menjadi acuan revisi media pembelajaran yang dikembangkan. Hasil revisinya perubahan mengunakan audio yang berupa instrument, dan penambahan tombol menu pada setiap slide. Terdapat beberapa perubahan yang peneliti lakukan sesuai dengan komentar dan saran yang disampaikan validator.

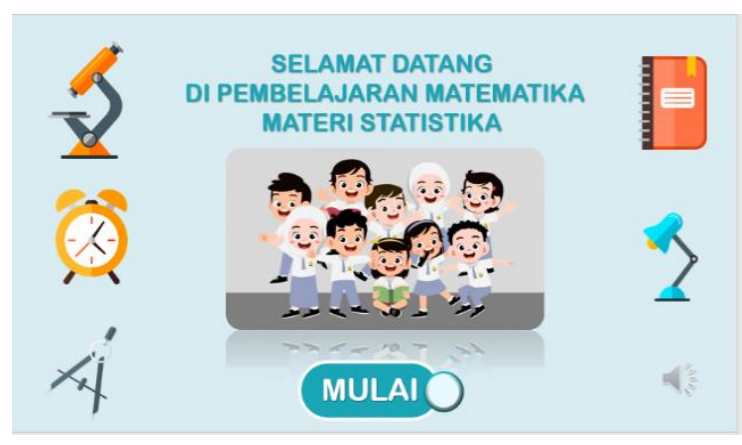

Gambar 6. Tampilan awal pada Bahan ajar melalui Aplikasi Ispring 


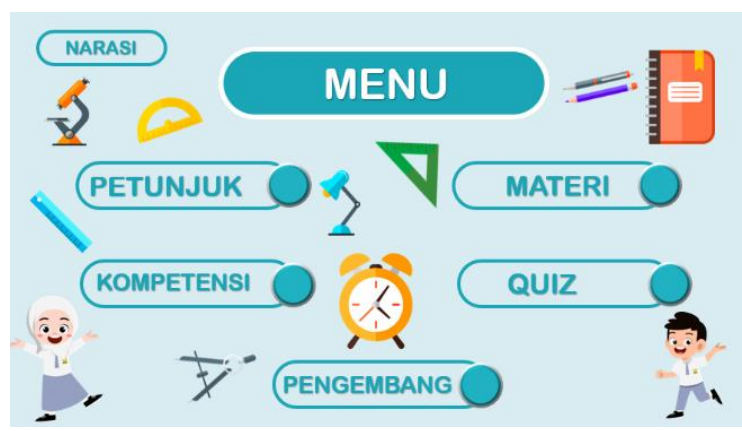

Gambar 7. Tampilan menu pada Bahan ajar melalui Aplikasi Ispring

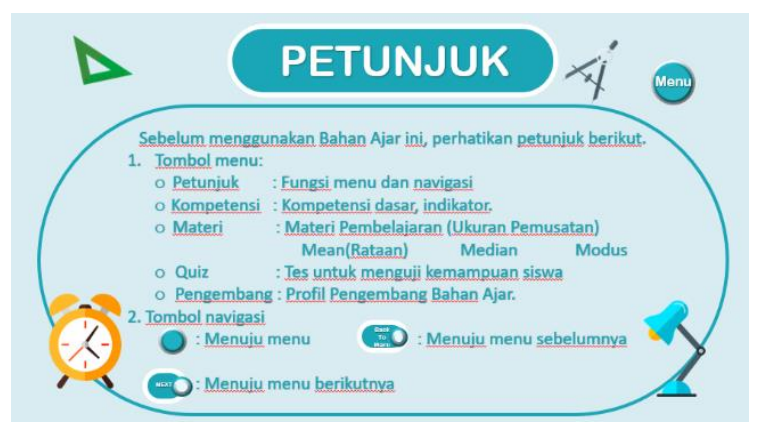

Gambar 8. Tampilan petunjuk pada Bahan ajar melalui Aplikasi Ispring

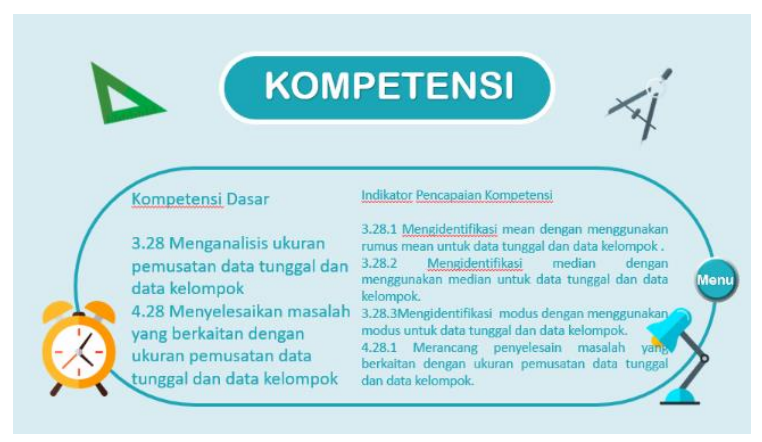

Gambar 9. Tampilan kompetensi pada Bahan ajar melalui Aplikasi Ispring

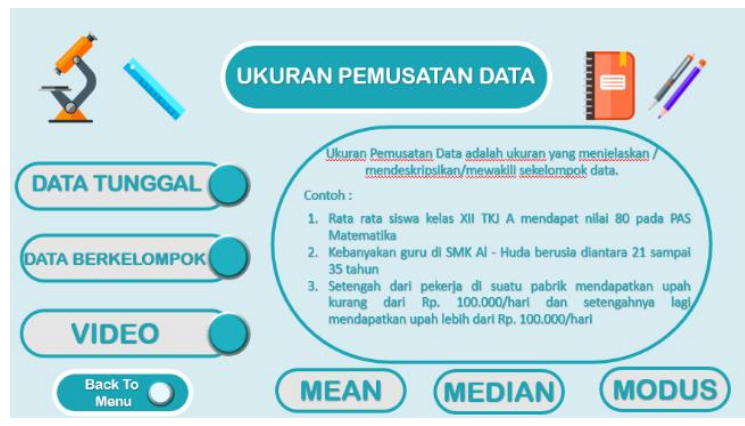

Gambar 10. Tampilan menu materi pada Bahan ajar melalui Aplikasi Ispring 
Pengembangan Bahan Ajar Interaktif Melalui Aplikasi Ispring untuk Mengeksplor Kemampuan Representasi Matematis, Irna Nuraeni, Nani Ratnaningsih, Sri Tirto Madawistama 1021

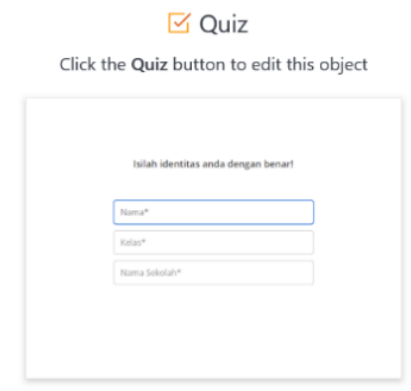

Gambar 11. Tampilan log in quiz pada Bahan ajar melalui Aplikasi Ispring

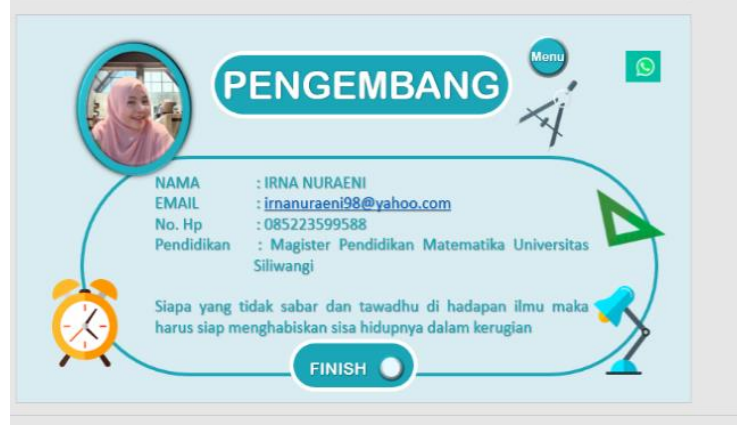

Gambar 12. Tampilan profil pengembang pada Bahan ajar melalui Aplikasi Ispring

\section{Implementation}

Implementasi (implementation) pada tahap ini adalah peneliti melakukan uji coba kepada siswa yaitu dengan subjek dari SMK Al - Huda Sariwangi uji coba sebanyak 8 siswa dengan menggunakan teknin simple random sampling, penelitian ini dilakukan pada 18 Oktober 2021. Kedelapan siswa ini mengamati dan mengikuti kegiatan penelitian serta memberikan masukan terhadap bahan ajar yang dikembangkan. Uji coba bahan ajar yang dikembangkan dilakukan sebanyak 1 kali. Kegiatan pertama yang dilakukan adalah memperkenalkan bahan ajar pembelajaran berbasis aplikasi pada materi satatistika kepada subjek penelitian. Pada mulanya, siswa tidak memahami penggunaan bahan ajar tersebut sehingga untuk peneliti harus menjelaskan tata cara mengoperasikan serta penggunaan pada bahan ajar yang sudah dikembangkan.

\section{Evaluation}

Tahap akhir yaitu evaluasi, peneliti melakukan penyempurnaan produk dengan mamperhatikan masukan dan saran dari berbagai pihak agar bahan ajar yang dikembangkan semakin berkualitas dan dapat memberikan manfaat sesuai dengan tujuan pengembangan. Hasil dari tahap ini merupakan evaluasi dari hasil analisis data pada tahap-tahap sebelumnya, yang menunjukkan hasil akhir produk bahan ajar melalui apalikasi ispring pada materi statistika untuk mengeskplor kemampuan representasi matematis valid dan dapat digunakan peserat didik dalam pemebalajaran. Bahan ajar ini berisi kompetensi, materi, video, contoh soal, latihan soal berupa quiz, serta profil pengembang. Penyajian bahan ajar interaktif melalui aplikasi ispring mudah diakses dengan peneliti membagikan link atau bentuk aplikasi sehingga peserta didik dapat langsung menginstal apliaksi 
ispring dengan mudah dan apliaksi ispring mempermudah peserta didik dalam belajar dimanapun dan kapanpun. Selanjutnya peneliti mengukur kualitas efektivitas bahan ajar melalui apliaksi ispring untuk mengsekplor kemampuan representasi matematis dengan didasarkan dari nilai pretest dan posttest yang dilakukan pada awal pembelajaran dan akhir pembelajaran peserta didik. Pretest diberikan kepada peserta didik pada awal pertemuan untuk mengetahui kemampuan awal peserta didik. Selama pembelajaran statistika, peserta didik menggunakan bahan ajar untuk pemeblajaran. Setelah peserta didik belajar dan memahami materi statistika, peneliti memberikan posttest. Dari hasil pretest dan posttest diperoleh data berikut.

- $\quad$ mean of posttest $=9,2$

- $\quad$ mean of pretest $=4,8$

- $\quad$ standard deviation of pretest $=2,4$

$$
\begin{gathered}
E S=\frac{\text { mean of posttest }- \text { mean of pretest }}{\text { standard deviation of pretest }} \\
\begin{array}{c}
E S=\frac{9,2-4,8}{2,4} \\
E S=\frac{4,4}{2,4} \\
E S=1,83
\end{array}
\end{gathered}
$$

Berdasarkan hasil perhitungan effect size, diperoleh bahwa nilai ES sebesar 1,83 yang termasuk dalam klasifikasi strong effect (Cohen, Manion, \& Marrison, 2007). Artinya, bahan ajar yang dikembangkan dapat digunakan dalam pembelajaran baru yang menarik bagi peserta didik. Selain itu, bahan ajar tersebut didukung dengan adanya keterbaharuan yaitu dapat diakses dengan smartphone/laptop/komputer, tersedia video, dan latihan soal yang sesuai dengan indikator kemampuan representasi matematis. Sesuai dengan penelitian yang dilakukan Tamami (2021) menyatakan bahwa pembelajaran menggunakan bahan ajar melalui apliaksi dapat meningkatkan hasil belajar peserta didik.

\section{KESIMPULAN}

Bahan ajar interaktif melalui aplikasi ispring untuk mengeskplor kemampuan representasi matematis yang telah dikembangkan menggunakan model pengembangan ADDIE termasuk dalam kategori valid dan layak digunakan berdasarkan penilaian dari ahli media dan ahli materi. Respon guru dan peserta didik terhadap bahana ajar yang dikembangkan tersebut memperoleh respon dengan kategori sangat baik berdasarkan hasil uji coba terbatas dan implementasi bahan ajar interaktif. Selain itu, kualitas efektivitas bahan ajar interaktif melalui aplikasi ispring untuk mengeskplor kemampuan representasi matematis memperoleh nilai effect size sebesar 1,83 yang berada pada kategori "strong effect", sehingga bahan ajar interaktif melalui aplikasi ispring sangat efektif untuk digunakan dalam pembelajaran. 
Pengembangan Bahan Ajar Interaktif Melalui Aplikasi Ispring untuk Mengeksplor Kemampuan Representasi Matematis, Irna Nuraeni, Nani Ratnaningsih, Sri Tirto Madawistama 1023

\section{UCAPAN TERIMA KASIH}

Dalam penelitian dan pembuatan artikel ini peneliti ingin mengucapakn terimakasih kepada dosen pembimbing yang tak lelah membimbing peneliti dalam melakukan penelitian dan pembuatan artikel ini.

\section{REFERENSI}

Al Adiyah, T, et al. (2018). Pengembangan Bahan Ajar Berbasis Komik "The Light of Life". Natural and Scieance Eduaction Research, 49-57.

Branch, R. M. (2009). Approach, Instructional Design: The ADDIE. In Department of Educational Psychology and Instructional Technology University of Georgia (Vol. 53, Issue 9).

Buyung, B., \& Nirawati, R. (2018). Pengaruh Karakter Kerja Keras terhadap Kemampuan Literasi Matematis Siswa melalui Model Discovery Learning. JPMI (Jurnal Pendidikan Matematika Indonesia), 3(1), 21-25.

Cahyati, A. D. (2018). Pengembangan Alat Evaluasi Pembelajaran Matematika dengan Ispring Suite 8. Lampung: Program Sarjana (Strata 1) di UIN Raden Intan Lampung.

Cohen, L., Manion, L., \& Morrison, K. (2007). Experiments, quasi-experiments, single-case research and meta-analysis. In Research Methods in Education. Routledge. https://doi.org/10.4324/9780203029053-23

Fajriah, N., Utami, C., \& Mariyam. (2020). Analisis Kemampuan Representasi Matematis Peserta didikpada Materi Statistika . Journal of Educational Review and Research 3(1), July hal $14-24$.

Hayati, S., Budi, A. S., \& Handoko, E. (2015). Pengembangan Media Pembelajaran Flipbook Fisika untuk Meningkatkan Hasil Belajar Peserta Didik. Prosiding Seminar Nasional Fisika (e-Jurnal) SNF2015, IV, 49-54.

Himmah, F., \& Martini. (2017). Pengembangan Multimedia Interaktif Menggunakan Ispring Suite 8 pada Sub Materi Zat Aditif untuk Meningkatkan Hasil Belajar Peserta didikSMP Kelas XII. EJournal Unesa. 5(2) 2017, 73 - 82.

Hosnan, M. (2016). Pendekatan Saintifik dan Konstektual dalam Pembelajaran Abad 21. (R. Sikumbang, Ed.) (3rd ed.). Bogor: Ghalia Indonesia.

Permata, J. I., Sukestiyarno Y.L., \& Hindarto, N. (2017). Analisis Representasi Matematis Ditinjau dari Kreativitas dalam Pembelajaran CPS dengan Asesmen Diagnostik. Unnes Journal of Mathematics Education Research. 6(2), Agustus hal. 233 - 241.

Rosmiati, U., \& Siregar, N. (2021). Promoting Prezi-PowerPoint presentation in mathematics learning: the development of interactive multimedia by using ADDIE model. Journal of Physics: Conference Series, 1957(1), 012007. https://doi.org/10.1088/1742-6596/1957/1/012007

Selviani. 2017. Pengembangan Bahan Ajar Matematika Berbasis Masalah Pada Pokok Bahasan Statistika Kelas XII MTsN Model Makassar. Skripsi UIN Alauddin Makasar.

Setiyani, S., Putri, D. P., \& Prakarsa, D. (2019). Designing Camtasia Software Assisted Learning 
Media Toward Students' Mathematical Comprehension in Numeral Material. Infinity Journal, 8(2), 143. https://doi.org/10.22460/infinity.v8i2.p143-156

Sugiyono. (2017). Metode Penelitian Pendidikan Pendekatan Kauntitatif, Kualitatif, R\&D. In Metode

Penelitian Pendidikan Pendekatan Kuantitatif, Kualitatif Dan R\&D.

Sundayana, Rostina. (2014). Statistika Penelitian Pendidikan. Bandung: PenerbitAlfabeta.

Tamami, Rosid. (2021). Pengembangan Bahan Ajar Interaktif Menggunakan Aplikasi Geogebra Pada Materi Lingkaran. Jurnal Teknodik, Vol. 25 - Nomor 1.

Zain, A. A., \& Pratiwi, W. (2021). Analisis Kebutuhan Pengembangan Media Powerpoint Interaktif Sebagai Media Pembelajaran Tematik Kelas V SD. Elementary School: Jurnal Pendidikan dan Pembelajaran Ke-SD-an, 8(1), 75 - 81.

Zakiy, M. A. Z., Syazali, M., \& Farida. (2018). Pengembangan Media Android dalam Pembelajaran Matematika. TRIPLE S:Jourals of Mathematics Education, 1(2), 87-96. 